\title{
Menggugat Sistem Kapitalisme
}

\author{
Oleh: Indah Piliyanti*
}

\begin{abstract}
The whole world is now in the grip of a financial crisis which is far more serious than any experienced since the Great Depression 1930. Mid of 2008, we all surprise that financial market down stairs seriously day by day. The US goverment has bailout more than three trillion dollars toward a number of industrial countries to abate somewhat the intensity of the crisis. The US goverment policy oppose capitalism paradigm: laissez faire. This article tries to discuss about capitalisme; history and the development in the global era. This economic system was fail overcome economic crises, even capitalism known as a cause of global financial crisis wordwide.
\end{abstract}

Keywords: economic crises, capitalism paradigm, Amerika, great depression.

\section{Pendahuluan}

Berawal dari kebangkrutan bank raksasa Lehman Brothers dan perusahaan finansial raksasa Bear Stearns di Amerika Serikat (AS), krisis ekonomi merambah hampir setiap negara dan menjadi isu global sejak 15 September 2008. Setelah kebangkutan perusahaan-perusahaan besar di AS, pasar keuangan yang selama ini menjadi urat nadi perekonomian dunia, mengalami gelombang kepanikan karena dari hari ke hari mengalami kemerosotan nilai dari efek-efek yang diperjualbelikan di bursa.

Pemerintah AS, mengeluarkan sebuah kebijakan untuk mengatasi kebangrutan tersebut dengan bailout terhadap sektor keuangan sebesar 700 milyar sampai 1 trilliun dolar AS. Menarik untuk disimak, ternyata AS yang dikenal menganut sistem ekonomi kapitalisme, dalam situasi panik karena krisis ekonomi mengambil kebijakan mengejutkan dengan melakukan intervensi pasar. Sebuah kebijakan yang yang bertentangan dengan paham pasar bebas (laissez faire) ${ }^{1}$, salah satu ajaran kapitalisme.

Ada banyak analisis terkait dengan kehancuran pasar finansial, mulai dari kebijakan defisit AS, kebijakan suku bunga rendah di era Greenspan, keserakahan elit politik, kegiatan spekulatif para petinggi perusahaan, seperti dilakukan Dick Fuld, CEO Lehman Brothers, tingginya biaya program politik luar negeri, manipulasi laporan keuangan dan lain-lain. ${ }^{2}$

*Dosen Ekonomi Islam STAIN Surakarta, email: iyanti@yahoo.com

${ }^{1}$ Laissez faire berasal dari frase bahasa Perancis yang berarti "biarkan terjadi" (secara harafiah "biarkan berbuat"). Istilah ini berasal dari diksi Perancis yang digunakan pertama kali oleh para fisiokrat di abad ke-18 sebagai bentuk perlawanan terhadap intervensi pemerintah dalam perdagangan. Laissez faire menjadi sinonim untuk ekonomi yang ketat selama awal dan pertengahan abad ke-19. Selanjutnya lihat dalam entri Wikipedia tentang Laissez faire pada http://id.wikipedia.org/wiki/Laissez-faire diakses pada 22 Juni 2009.

${ }^{2}$ Agustianto. (2008). Akar Krisis Kenangan Global: Bubble Economy dan Fenomena Ribawi (bagian tiga). Dikutip dari http://www.pkesinteraktif.com/content/view/3129/36/lang,id/ diakses pada 6 Juni 2009.

\section{La_Riba}

JURNAL EKONOMI ISLAM

Volume III, No. 1, Juli 2009 
Indah Piliyanti: Menggugat Sistem Kapitalisme

Diakui oleh banyak ekonom, guncangan ekonomi akibat krisis keuangan yang melanda AS merupakan guncangan yang terparah setelah Great Depresion pada 1930an. Ini merupakan kegagalan sistem kapitalisme dalam menjawab berbagai persoalan ekonomi yang muncul. Karenanya, menarik untuk mengetahui lebih jauh tentang sistem ekonomi kapitalis yang dianut oleh AS dan disebut-sebut sebagai penyebab krisis ekonomi. Pembahasan dalam artikel ini di awali dengan mengenal sistem kapitalisme: definisi, sejarah munculnya, tokoh dan ajaran, serta kelemahan kapitalisme sebagai sebuah sistem ekonomi. Pembahasan diakhiri dengan kesimpulan penutup.

\section{Mengenal Sistem Ekonomi Kapitalisme}

'It's not from the benevolence of the buthcer that we expect our dinner, but from bis regard to bis own interest's

Kutipan di atas adalah salah satu pendapat Adam Smith yang menjadi salah satu pengingat kita pada sistem ekonomi kapitalisme bahwa tindak tanduk manusia pada umumnya didasarkan pada kepentingan diri sendiri (self interest), bukan belas kasihan dan juga bukan perikemanusiaan. Sebelum jauh mengenal sistem ekonomi kapitalisme, terlebih dahulu akan di bahas definisi kapitalisme.

\section{A. Definisi Kapitalisme sebagai Sistem Ekonomi}

Kapitalisme dalam kamus bahasa Indonesia di artikan sebagai sebuah sistem dan paham ekonomi (penanaman modalnya, kegiatan industrinya) bersumber pada modal pribadi atau modal perusahaan swasta dengan ciri persaingan dan pasar bebas. ${ }^{4}$

Wikipedia mendefinisikan kapitalisme sebagai suatu paham yang meyakini bahwa pemilik modal bisa melakukan usahanya untuk meraih keuntungan sebesarbesarnya. Demi prinsip tersebut, maka pemerintah tidak dapat melakukan intervensi pasar guna keuntungan bersama. Walaupun demikian, kapitalisme sebenarnya tidak memiliki definisi universal yang bisa diterima secara luas. ${ }^{5}$

Beberapa ahli mendefinisikan kapitalisme sebagai sebuah sistem yang mulai berlaku di Eropa pada abad ke-16 hingga abad ke-19, yaitu pada masa perkembangan perbankan komersial Eropa di mana sekelompok individu maupun kelompok dapat bertindak sebagai suatu badan tertentu yang dapat memiliki maupun melakukan perdagangan benda milik pribadi, terutama barang modal, seperti tanah dan manusia guna proses perubahan dari barang modal ke barang jadi. ${ }^{6}$

${ }^{3}$ Pendapat ini, termuat dalam buku ke-2 yang di tulis Adam Smith, berjudul An Inquiry into the Nature and Causes of the Wealth of the Nations (1776) atau disingkat dengan the Wealth of the Nations. Buku pertama the Moral Sentiment dilupakan banyak orang. Padahal, isi buku pertama menjadi landasan utama dalam berekonomi yang ditawarkan Adam Smith yakni moral.

${ }^{4}$ Tim Redaksi (2005). Kamus Besar Bahasa Indonesia. edisi ketiga, (Jakarta: Balai Pustaka). p. 505.

5http://id.wikipedia.org/wiki/Kapitalisme diakses pada 22 Juni 2009.

${ }^{6}$ Ibid. Ekonomi Kapitalisme itu adalah nama lain dari liberalisme di bidang ekonomi. Artinya, dalam bidang ekonomi, seorang individu dibebaskan untuk memiliki apapun dengan cara apapun. Tidak ada lagi batas-batas kepemilikan mana yang boleh dimiliki individu mana yang boleh dimiliki oleh negara dan 
Indah Piliyanti: Menggugat Sistem Kapitalisme

Menurut Deliarnov, ${ }^{7}$ sistem ekonomi adalah interaksi dari unit-unit ekonomi yang kecil (para konsumen dan produsen) ke dalam unit ekonomi yang lebih besar, di suatu wilayah tertentu. Dalam suatu sistem ekonomi tercakup seluruh proses dan kegiatan masyarakat dalam usaha mereka memenuhi kebutuhan yang terbatas.

Sistem ekonomi yang dianut tiap kelompok masyarakat atau negara tidak sama. Hal ini tergantung dari keputusan dasar tentang pemilikan, produksi, distribusi serta konsumsi dilakukan. Ada keputusan-keputusan yang lebih diserahkan pada orang per orang (swasta) atau yang dikenal dengan sistem liberal/kapitalisme dan ada pula yang harus diatur oleh pusat atau sosialisme ${ }^{8}$.

Dalam suatu sistem ekonomi tercakup nilai-nilai, kebiasaan, adat istiadat, hukum, norma-norma, aturan berikut kesepakatan akan tujuan bersama otoritas dan kekuasaan untuk mengerahkan sumber daya yang ada untuk tujuan bersama. Sistem perekonomian yang dianut oleh suatu bangsa (negara atau sekelompok masyarakat) tergantung dari doktrin, mazhab, atau aliran pandangan ekonomi yang pada gilirannya juga dipengaruhi oleh seperangkat nilai (set of values) yang dianut oleh bangsa atau kelompok masyarakat tersebut (seperti adat, kebiasaan, norma-norma, kepercayaan, ideologi, falsafah). ${ }^{9}$

\section{B. Sejarah dan Pekembangan Kapitalisme}

Persoalan ekonomi sama tuanya dengan sejarah keberadaan manusia di dunia. Namun, pemikiran ekonomi sebagai sebuah hasil pergulatan manusia dengan kondisi lingkungan masyarakat, dapat dilacak sejak 400 SM dari para filosof pada masa Yunani kuno. Setidaknya Plato dan Aristoles membahas masalah ekonomi dalam pemikiran filsafatnya. ${ }^{10}$

masyarakat, sudah tidak ada lagi batasannya, semua boleh dimiliki individu. Aturan yang berlaku hanyalah aturan yang dibuat dan disepakati diantara kaum kapitalis itu. Aturan bisa diubah ketika mereka menganggap aturan itu perlu diubah ketika melihat aturan itu bisa merugikan mereka, selanjutnya lihat dalam Taufik Adi Susilo. (2009). Mengenal Amerika Serikat, cet 1. (Yogyakarta: Ar-Ruzz Media). p. 88.

7Deliarnov. (2005). Perkembangan Pemikiran Ekonomi, (Jakarta: Raja Grafindo Persada). p. 3.

${ }^{8}$ Setidaknya, ada dua aliran besar yang memiliki pandangan ekstrim tentang persoalan ekonomi dalam sepanjang sejarah pemikiran ekonomi modern, yakni Kapitalisme dan Sosialisme. Walaupun, dari kedua mazhab ini, lahir banyak cabang pemikiran, namun garis besar pemikirannya mengacu pada dua aliran besar tersebut. Misalnya mazhab neoklasik, merupakan hasil pemikiran ekonom klasik yang mengalami pembaruan dan seterusnya. Hampir 30 tahun belakangan, gelombang perhatian tertuju pada sebuah sistem yang sebenarnya telah digagas dan dipraktikkan sejak abad 7 Masehi ketika Islam berkembang. Namun, umat Islam baru mulai serius menggali konsep ekonomi tersebut di abad ini. Bahkan, sistem ekonomi Islam saat ini dapat disebut sebagai promising economic system atas solusi kegagalan ekonomi kapitalisme maupun sosialisme.

${ }^{9}$ Deliarnov. (2005). Op.cit., p. 4.

${ }^{10}$ Kontribusi kedua filosof ini dalam bidang ekonomi misalnya dapat diketahui dari buku yang mereka tulis. Pemikiran Plato misalnya tentang fungsi uang yang masih relevan dengan keadaan sekarang ini. Aristoteles memberi kontribusi paling besar terhadap ilmu ekonomi melalui pemikirannya tentang pertukaran barang dan kegunaan uang dalam pertukaran tersebut. Selanjutnya baca dalam Deliarnov. (2005). Op.cit. p. 14 15. Setidaknya hal tersebut menjadi bukti bahwa pemikiran ekonomi telah menjadi kajian serius diantara para filosof sebelum masehi sesuai dengan dinamika masyarakat yang terjadi di masa itu. Selain kedua filosof tersebut, Xenophone adalah seorang filosof Yunani yang pertama kali menggunakan istilah ekonomi. Ekonomi sendiri berasal dari penggabungan dua suku kata Yunani: oikos dan nomos. 
Pasca periode Yunani kuno, penulisan sejarah perkembangan pemikiran ekonomi melompat pada periode skolastik. ${ }^{11}$ Menurut Landerth (1976), sejak abad ke-15, ketika masyarakat petani Eropa memulai proses industrialisasi, cabang ilmu sosial yang berhubungan dengan analisis ekonomi muncul. Kemunculan tersebut karena lahirnya pemikiran-pemikiran ekonomi dari kaum skolastik (scholasticism). ${ }^{12}$

Sedangkan Kapitalisme, muncul di Eropa Barat di akhir abad ke-15 tepatnya pada 1492, ketika Cristoper Columbus menemukan benua Amerika. ${ }^{13}$ Penemuan ini kemudian disusul dengan penemuan jalur jalan laut langsung ke India oleh Vasco Da Gamma. Sistem kapitalisme awal (1500-1750) ditandai dengan kebijakankebijakan merkantilis yang indentik dengan penumpukan emas dan perak. Kapitalisme awal ini juga ditandai dengan munculnya imperium-imperium di Eropa Barat seperti Spanyol, Portugis, Belanda, Prancis dan Inggris. Kerakusan antar imperum kapitalis ini membuat mereka saling berperang untuk menjajah bangsabangsa lain agar bisa memperebutkan harta.

Yang pertama menerapkan kapitalisme adalah AS dan Prancis. Pada abad 19, mulai banyak negara-negara yang menerapkan kapitalisme seperti Inggris, Belanda, Jerman, dan Belgia. Pada 1868, Jepang menjadi negara kapitalis. Pada 1900, sudah ada 13 negara yang menerapkan kapitalisme. Setelah perang dunia ke dua, AS mucul sebagai negara kapitalis nomor 1 di dunia. ${ }^{14}$

Akhir abad ke 17-18 adalah masa kristalisasi liberalisme dalam bentuk hak asasi manusia dan demokrasi di Eropa barat dan Amerika utara. Semangat liberalisme ini meledak dalam revolusi Amerika (1775) dan revolusi Prancis (1789) sehingga di akhir abad ke-19 mulaiah kapitalisme yang berbasis ideologi liberalisme diterapkan oleh negara.

\section{Tokoh dan Ciri-Ciri Kapitalisme}

Adam Smith merupakan tokoh mazhab klasik dan dapat dikatakan sebagai bapak kapitalisme. Ia dilahirkan di kota Kirkcaldy, Country File di Skotlandia tahun

${ }^{11}$ Padahal, pada awal abad 7 Masehi, Islam datang dengan seperangkat sistem yang lengkap bagi umat manusia yang mencakup berbagai jawaban atas persoalan hidup. Kontribusi kaum muslim yang sangat besar terhadap kelangsungan dan perkembangan pemikiran ekonomi pada khususnya dan peradaban dunia pada umumnya, telah diabaikan oleh para ilmuwan barat. Buku-buku teks ekonomi barat hampir tidak pernah menyebutkan peranan kaum muslim ini. Para sejarawan barat telah menulis sejarah ekonomi dengan sebuah asumsi bahwa periode antara Yunani dan Skolastik adalah steril dan tidak produktif. Sebagai contoh, sejarawan sekaligus ekonom terkemuka, Joseph Schumpeter, sama sekali mengabaikan peranan kaum muslim. Ia memulai penulisan sejarah ekonominya dari para filosof Yunani dan langsung melakukan loncatan jauh selama 500 tahun, dikenal dengan Great Gap, ke zaman Thoman Aquinas. Selanjutnya lihat dalam: Adiwarman A Karim. (2004). Sejarah Pemikiran Ekonomi Islam, edisi kedua. (Jakarta: Raja Grafindo Persada). p. 9.

${ }^{12}$ Ada dua tokoh utama dari aliran Scholastik, yakni St. Albertus Magnus dan St. Thomas Aquinas. Setelah kedua aliran ini, muncul pula mazhab Merkantilisme dan Fisiokrat. Kedua mazhab ini kemudian banyak memberi warna pada hasil pemikiran Adam Smith. Oleh karena itu, Adam Smith dikenal sebagai tokoh pemikiran klasik -sebutan klasik diungkapkan oleh Karl Marx- karena gagasan pemikiran ekonominya diilhami oleh pemikiran ekonomi kedua mazhab ini, bukan murni dari pemikirannya. Misalnya laissez faire, laissez passer sudah dibicarakan oleh Francis Quesnay (tokoh mazhab fisiokrat). Selanjutnya dalam Deliarnov. (2005). Op.cit., p. 11-25.

${ }^{13}$ Taufik Adi Susilo. (2009). Mengenal Amerika Serikat, Cet 1. (Yogyakarta: Ar-Ruzz Media). p. 88.

${ }^{14}$ Ibid. p. 89. 
Indah Piliyanti: Menggugat Sistem Kapitalisme

1723. Adam Smith selain terkenal karena pemikirannya mengenai filsafat dan ilmu ekonomi, ia juga mempunyai kepribadian yang menakjuban. Mengajar kuliah logika di Universitas Glasgow pada tahun 1751 dan pada tahun 1759 ia menerbitkan buku yang berjudul: the Theory of Moral Sentimens, buku inilah awal ditempatkannya Adam Smith di barisan terdepan ahli-ahli pikir Inggris. ${ }^{15}$

Sejarah mencatat, Adam Smith merupakan orang pertama yang dikenal mengumpulkan ide dan gagasan yang berserak dari para pemikir ekonomi sebelumnya ke dalam sebuah buku: the Wealth of the Nations. Di kemudian hari, Karl Marx-lah yang memberi julukan mazhab klasik bagi ide-ide Adam Smith yang merupakan ide para pemikir sebelumnya, bukan ide murninya. Buku ini merupakan buku keduanya dan dijadikan sebagai buku utama dalam mazhab klasik. Buku pertama Adam Smith yang menempatkan moral sebagai pijakan dalam kegiatan ekonomi, dilupakan banyak orang.

Ajaran tentang doktrin perekonomian liberal yang berasal dari Adam Smith menandai adanya suatu perubahan yang revolusioner dalam pemikiran ekonomi. Pada masa-masa sebelumnya, terutama masa merkantilis, peran negara sangat tinggi atas individu-individu. Akan tetapi, sejak era Smith kepentingan individu lebih diutamakan. Kepentingan negara tidak hanya dinomorduakan, bahkan lebih dari itu, negara justru diberi tugas demi menjamin tercapainya kondisi bagi setiap orang untuk bebas bertindak melakukan yang terbaik bagi diri mereka masing-masing. ${ }^{16}$

Umer Chapra menyebutkan lima ciri Kapitalisme:

1. Percaya bahwa ekspansi kekayaan dapat dipercepat, produksi maksimum dan pemuasan keinginan sesuai dengan preferensi individu sangat penting bagi kesejahteraan;

2. Kebebasan individu tanpa batas untuk menciptakan kekayaan pribadi, memiliki dan mengaturnya sebagai keharusan bagi inisiatif individu;

3. Inisiatif individu dan pengambilan keputusan dalam pasar bebas sebagai syarat efisiensi optimum alokasi sumber daya;

4. Tidak perlu peran pemerintah dan nilai-nilai kolektif dalam efisiensi alokasi dan keadilan distribusi;

5. Pemenuhan kepentingan pribadi oleh semua individu secara otomatis akan memenuhi kepentingan sosial. ${ }^{17}$ p. 42.

${ }^{15}$ Bachrawi Sanusi. (2004). Tokoh Pemikir dalam Mazhab Ekonomi, Cet pertama( Jakarta: Rineka Cipta)

${ }^{16}$ Deliarnov (2004). Op.cit., p. 40. Pada intinya, sistem kapitalisme bersandar atas kebebasan dalam melakukan kegiatan ekonomi (kebebasan kepemilikan, transaksi, produksi, penentuan upah dan harga, konsumsi, serta kebebasan untuk mendistribuksan pendapatan dan kekayaan). Semua kesepakatan yang ada berdasarkan atas mekanisme pasar bebas yang membentuknya, dengan tujuan meraih keuntungan materi bagi pihak yang terlibat dalam transaksi. Selanjutnya lihat dalam Said Sa'ad Marthon. (2001). Ekonomi Islam di Tengah Krisis Ekonomi Global, cet 1.(Jakarta: Zikrul Hakim), p. 10.

${ }^{17}$ Selanjutnya lihat dalam Zakiyuddin Baidhawy. (2007). Islam Melawan Kapitalisme, (Yogyakarta: Resist Book). p. 3.

50 La_Riba

JURNAL EKONOMI ISLAM

Volume III, No. 1, Juli 2009 
Indah Piliyanti: Menggugat Sistem Kapitalisme

Kapitalisme dalam bentuk klasiknya laissez, faire telah runtuh, yang masih bertahan hingga kini dalah kapitalisme yang telah dimodifikasi. ${ }^{18}$ Setelah krisis kapitalisme selama 25 tahun terakhir dan semakin berkurangnya tingkat profit yang berakibat jatuhnya akumulasi kapital, meneguhkan tekad korporasi bersar untuk kembali ke liberalisme. Melalui corporate globalization mereka merebut kembali ekonomi dan berhasil mengembalikan paham liberalisme, bahkan dalam skala global. Inilah yang disebut sebagai paham neoliberalisme. ${ }^{19}$

\section{Kelemahan Kapitalisme}

Salah satu pokok pikiran kapitalisme yang memberi kebebasan bagi setiap orang dalam aktivitas ekonomi, tidak serta merta menjadikan masyarakat menjadi makmur dan sejahtera. Sebaliknya, memunculkan berbagai ketimpangan sosial. Diantara kelemahan sistem kapitalis antara lain:

1. Munculnya kesenjangan perimbangan dalam distribusi antar individu dan sarana-sarana produksi hanya akan terkumpul pada satu kelompok. Pengaruh semangat materialis akan membagi masyarakat ke dalam dua kelompok, golongan kaya dan miskin. ${ }^{20}$ Senada dengan at-Tariqi, Baidhawy berpendapat bahwa sisi lain kekurangan kapitalisme terletak pada alternatif utamanya untuk meningkatkan standar hidup kaum miskin melalui pertumbuhan ekonomi (economic growth) dan developmentalisme. Suatu pengurangan dalam ketidakmerataan pendapatan tidak dapat terjadi kecuali ketika pendapatan total meningkat lebih cepat dibandingkan penduduk. Penghasilan hanya dapat ditingkatkan melalui peningkatan produk. Individu dipandang akan bahagia dengan pendapatan baru yang tinggi. ${ }^{21}$

2. Timbulnya krisis dan merajalelanya kejahatan karena meningkatnya pengganguran yang disebabkan banyaknya produsen yang berhenti berproduksi dan menutup pabrik. Hal ini disebabkan karena produsen komoditas sebagai kebutuhan mewah tertentu meningkat demi memenuhi kebutuhan-kebutuhan pemilik modal besar, dan langkah ini memaksa pasar untuk menyerapnya. ${ }^{22}$ Krisis ekonomi global tahun 2008 ini, ternyata bukan pertama kalinya terjadi. Sejarah mencatat, krisis ekonomi selalu berulang dan menimbulkan dampak bukan hanya bidang ekonomi, tetapi juga dampak sosial yang besar di tengah masyarakat dunia.

${ }^{18}$ Dua peristiwa yang menggugurkan kapitalisme laissez faire berkaitan dengan prinsip non intervensi pemerintah dalam ekonomi adalah Depresi besar tahun 1930-an dan serangan kaum sosialis yang melahirkan revolusi Keynesian dan negara kesejahteraan. Selanjutnya baca dalam Zakiyuddin Baidhawy. (2007). Op.cit., p. 3 .

${ }^{19}$ Bapak ekonomi neoliberalisme adalah Friederich August von Hayek dan Milton Friedman. Mulai dekade 1980-an aliran kanan baru yang diwakili oleh Margaret Thacher dan Ronald Reagan memperjuangkan pasar bebas dan dengan tegas menolak paham negara intervensionis. Tahun 1990-an, kapitalisme neoliberal, pasar bebas, dari dua tokoh tersebut telah menjadi ideologi dunia yang dominan. Selanjutnya lihat dalam Zakiyuddin Baidhawy. (2007). Op.cit., p. 8.

${ }^{20}$ Abdullah A. Husain at-Tariqi. (2004). Ekonomi Islam: Prinsip, Dasar, dan Tujuan, cetakan pertama. (Yogyakarta: Magistra Insania Press), p. 42.

${ }^{21}$ Zakiyuddin Baidhawy. (2007). Op.cit., p. 5.

${ }^{22}$ Abdullah A Husain at-Tariqi. (2004). Op.cit., p. 42. 
Indah Piliyanti: Menggugat Sistem Kapitalisme

Akibat krisis ekonomi global, Organisasi Perburuhan Dunia (ILO) memperkirakan sekitar 20 juta orang akan kehilangan pekerjaannya hingga akhir 2009. Jumlah ini akan semakin meningkatkan jumlah pengangguran global dari 190 juta orang pada tahun 2007 menjadi 210 juta orang pada akhir tahun 2009. Peningkatan jumlah pengangguran secara fantastis ini mengancam terjadinya krisis sosial global. Menurut Joan Somavia, Direktur ILO, krisis ekonomi global bukan hanya krisis pasar modal Wall Street saja, tapi akan berdampak pula terhadap kehidupan sosial masyarakat. ${ }^{23}$

Berikut adalah kronologi krisis ekonomi yang terjadi dalam lintasan sejarah ekonomi:

a) Kepanikan 1797. Akibat kepanikan 1797 ini krisis ekonomi berlangsung selama 3 tahun dari 1797 hingga 1800. Deflasi Bank of England yang menyebar hingga lautan Atlantik dan Amerika Utara dan menyebabkan hancurnya perdagangan dan pemasaran real estat di Amerika Serikat dan sekitar Karibia. Ekonomi Inggris terpengaruh akibat adanya pembalikan deflasi selama perang dengan Perancis saat terjadinya revolusi Perancis.

b) Depresi 1807. Depresi ini terjadi selama tujuh tahun sejak 1807 hingga 1814. Undang-undang embargo AS 1807 pada saat itu diluluskan oleh kongres Amerika saat presiden Thomas Jefferson memimpin. Hal ini menghancurkan industri yang terkait dengan perkapalan. Kaum federal berusaha melawan embargo ini dan berusaha melakukan penyelundupan di New England.

c) Kepanikan 1819. Krisis akibat kepanikan ini terjadi selama 5 tahun dari 1819 hingga 1824. Ini adalah krisis finansial pertama yang mempengaruhi keuangan AS secara besar-besaran, bank-bank berjatuhan, munculnya pengangguran, dan merosotnya pertanian dan industri manufaktur. Ini juga menandakan berakhirnya ekspansi ekonomi yang mengikuti Perang 1812.

d) Kepanikan 1837. Kepanikan ini berlangsung antara 1837 hingga 1843. Ekonomi AS jatuh secara tajam disebabkan kegagalan bank dan kurangnya keyakinan pada uang kertas. Spekulasi pasar menyebabkan bank di AS berhenti bertransaksi dalam bentuk koin emas dan perak.

e) Kepanikan 1857. Kepanikan ini terjadi selama tiga tahun hingga tahun 1860. Kejatuhan Perusahaan Asuransi Hidup dan Kepercayaan Ohio menimbulkan ledakan spekulasi di sektor transportasi AS. Lebih dari 5.000 bisnis gagal kurang dari setahun sejak terjadinya kepanikan dan para penganggur melakukan protes di kawasan urban.

f) Kepanikan 1873. Kepanikan ini terjadi selama enam tahun disebabkan masalah ekonomi di Eropa yang mengakibatkan jatuhnya Jay Cooke \& Company, bank terbesar di AS. Hal ini juga menimbulkan spekulasi terhadap perang saudara di AS. Undang-undang koin 1873 juga memberikan kontribusi dalam jatuhnya harga perak yang menghancurkan industri pertambangan Amerika Utara.

${ }^{23}$ Dikutip dari: Dampak Krisis Ekonomi Global: 210 Juta orang akan menjadi Penggangguran, dalam http://detikislam.com/2008/10/21/dampak-krisis-ekonomi-global-210-juta-orang-akan-menjadipengangguran/ diakses pada 6 Juni 2009. 
Indah Piliyanti: Menggugat Sistem Kapitalisme

g) Depresi Berkepanjangan. Sesuai namanya, depresi ini menelan waktu 23 tahun sejak 1873 hingga 1896. Runtuhnya Bursa Efek Vienna menyebabkan depresi ekonomi yang menyebar ke seluruh dunia. Ini sangat penting dicatat dimana pada periode ini, produksi industri global meningkat pesat. Di AS misalnya, pertumbuhan produksi mencapai empat kali lipat.

h) Kepanikan 1893. Kepanikan ini terjadi selama tiga tahun hingga 1896 akibat kegagalan Reading Railroad Amerika Serikat dan penarikan investor Eropa terhadap pasar saham serta jatuhnya bank-bank.

i) Resesi Perang Dunia I. Resesi ini terjadi selama tiga tahun hingga 1921. Terjadinya hiperinflasi di Eropa menyebabkan kelebihan produksi besarbesaran di Amerika Utara.

j) Depresi Besar 1929. Depresi ini merupakan yang paling besar dan dikenang sepanjang sejarah terjadi selama 10 tahun sejak 1929 hingga 1939. Pasar saham di seluruh dunia saat itu berjatuhan dan bank-bank di AS mengalami kebangkrutan. Jutaan pengangguran bermunculan dan kemiskinan merajalela.

k) Resesi 1953. Resesi ini terjadi selama satu tahun. Setelah periode inflasi perang Korea berakhir, banyak uang yang ditransferkan untuk keamanan nasional AS. Berubahnya kebijakan The Fed yang lebih membatasi pada tahun 1952 menyebabkan terjadinya inflasi yang lebih lanjut.

1) Krisis Minyak 1973. Krisis ini terjadi selama dua tahun hingga 1975. Naiknya harga minyak yang ditetapkan oleh OPEC dan tingginya biaya yang dikeluarkan AS pada Perang Vietnam menyebabkan terjadinya stagflasi di AS.

m) Resesi Awal 1980. Resesi ini terjadi di awal tahun 1980 selama dua tahun. Revolusi Iran membuat melonjaknya harga minyak dan munculnya krisis energi 1979. Pergantian rezim di Iran menyebabkan menurunnya pasokan minyak sehingga harga minyak melambung. Ketatnya kebijakan moneter di AS untuk mengontrol inflasi menyebabkan terjadi resesi lainnya.

n) Resensi Awal 1990. Resesi ini terjadi selama satu tahun dimana perdagangan produk industri dan manufaktur menurun.

o) Resesi Awal 2000. Resesi ini terjadi selama dua tahun dari 2001 hingga 2003. Keruntuhan bisnis dot-com, serangan 11 September, dan skandal pembukuan menyebabkan krisis di sekitar Amerika Utara.

p) Depresi Ekonomi 2008. Depresi inilah yang saat ini tengah melanda dunia. Hal ini disebabkan beberapa faktor diantaranya naiknya harga minyak yang menyebabkan naiknya harga makanan di seluruh dunia, krisis kredit dan bangkrutnya berbagai investor bank, meningkatnya pengangguran sehingga menyebabkan inflasi global. Bursa saham di beberapa negara terpaksa 
Indah Piliyanti: Menggugat Sistem Kapitalisme

ditutup beberapa hari termasuk di Indonesia, harga-harga saham juga turut anjlok. Diperkirakan depresi ekonomi kali ini separah/ lebih parah dari depresi besar ekonomi 1929. ${ }^{24}$

3. Meningkatnya praktik monopoli secara empiris aplikatif dan yuridis sebagai bagian dari usaha untuk melemahkan semangat persaingan. Regulasi-regulasi monopoli dan semi monopoli sering ditujukan untuk mengeruk keuntungan yang masih dapat diraih dengan jalan aturan hukum dalam produksi dan peningkatan biaya (cost) melalui strategi penguatan aturan-aturan produksi. Banyak pihak dengan sengaja menghancurkan bahan produksi dan melarang bidang pertanian atau industri beberapa komoditas tertentu dengan tujuan untuk menaikkan harga. Akibatnya, semangat kerjasama, simpati, persamaan, dan saling menjamin akan hilang dari kehidupan bermasyarakat. ${ }^{25}$ Di negaranegara kapitalis sendiri berkembang suatu pandangan skeptis mengenai mekanisme pasar bebas. Kekurangmampuan pasar bebas untuk mencapai keadilan yang diharapkan dalam pemanfaatan sumber daya semakin terbukti. Demikian pula persaingan sempurna sesungguhnya belum pernah tercapai. Pada saat yang sama, praktik monopoli dan oligopoli berperan besar dalam menciptakan ketidakadilan pendapatan dan kekayaan. ${ }^{26}$

4. Kebebasan tanpa batas dalam pekerjaan dan alokasi kekayaan. ${ }^{27}$

\section{Penutup}

Sistem ekonomi yang dianut tiap kelompok masyarakat atau negara tidak sama. Hal ini tergantung dari keputusan dasar tentang pemilikan, produksi, distribusi serta konsumsi dilakukan. Sistem tersebut mencerminkan nilai-nilai yang dianut oleh masyakarat setempat. Dalam sejarah pemikiran ekonomi konvensional, terdapat dua aliran besar sistem ekonomi di dunia: kapitalisme dan sosialisme. Sistem ekonomi kapitalisme mendasarkan pada mekanisme pasar, dimana tidak ada campur tangan pemerintah dalam bidang ekonomi.

Sistem ekonomi kapitalisme gagal mengatasi masalah-masalah ekonomi; pengangguran, kemiskinan dan lain-lain. Salah satu bukti nyata, krisis ekonomi berulang terjadi di sepanjang sejarah. Krisis ekonomi tahun 2008 merupakan krisis terbesar sepanjang sejarah bahkan dari great depression tahun 1930-an. Krisis ekonomi kali ini berawal dari kebangkrutan pasar keuangan di AS.

\footnotetext{
${ }^{24}$ Sejarah Krisis Ekonomi Dunia dikutip dari http://www.lintasberita.com/Sains/Sejarah_Krisis_Ekonomi_Dunia diakses pada 6 Juni 2009. Referensi lain, seperti dikutip Ali Sakti dari Roy \& Glyn Davies (1996), the History of Money From Aciant time to Present Day dan Francisco LR dan Luis R Batiz (1985) tentang kronologi krisis keuangan, dimulai sejak tahun 1860-1921 Peningkatan Jumlah Bank di AS sampai dengan 19 Kali Lipat, 1907 Krisis Perbankan Internasional dimulai di New York, 1913 US Federal Reserve Sistem1914 - 1918 Perang Dunia I, setelah itu menyebar di berbaga negara sampai 20 kali dalam sejarah, selanjutnya dalam http://www.mail-archive.com/ekonomisyariah@yahoogroups.com/msg03106.html.

${ }^{25}$ Abdullah A Husain at-Tariqi. (2004). Op.cit., p. 42.

26Zakiyuddin Baidhawy. (2007). Op.cit.

${ }^{27}$ Abdullah A Husain at-Tariqi. (2004). Op.cit., p. 42.
}

\section{La Riba} JURNAL EKONOMI ISLAM

Volume III, No. 1, Juli 2009 
Indah Piliyanti: Menggugat Sistem Kapitalisme

Kapitalisme dalam wujud asalnya laissez faire telah runtuh. Terbukti AS, sebagai negara pertama penganut kapitalisme, pada saat krisis ekonomi tahun lalu mengeluarkan kebijakan yang mengejutkan: bailout terhadap kebangkutan pasar keuangan, kebijakan yang bertentangan dengan laissez faire.

\section{DAFTAR PUSTAKA}

Agustianto. (2008). Akar Krisis Kenangan Global: Bubble Economy dan Fenomena Ribawi (bagian tiga), dikutip dari http://www.pkesinteraktif.com/content/view/3129/36/lang,id/ diakses pada 6 Juni 2009.

At-Tariqi, Abdullah A Husain. (2004). Ekonomi Islam Prinsip, Dasar dan Tujuan, cetakan pertama. Yogyakarta: Magistra Insania Press.

Baidhawy, Zakiyuddin. (2007). Islam melawan Kapitalisme, Yogyakarta: Resist Book.

Dampake Krisis Ekonomi Global: 210 Juta orang akan menjadi Penggangguran, dikutip dari http://detikislam.com/2008/10/21/dampak-krisis-ekonomi-global-210-jutaorang-akan-menjadi-pengangguran/ diakses pada 6 Juni 2009.

Definisi Kapitalisme dikutip dari http://id.wikipedia.org/wiki/Kapitalisme diakses pada 22 Juni 2009.

Definisi Laizess Faire dikutip dari http://id.wikipedia.org/wiki/Laissez-faire diakses pada 22 Juni 2009.

Karim, Adiwarman A. (2004), Sejarah Pemikiran Ekonomi Islam, edisi kedua. Jakarta: Raja Grafindo Persada.

Marthon, Said Sa'ad. (2001). Ekonomi Islam di tengah Krisis Ekonomi Global, cet 1. Jakarta: Zikrul Hakim.

Sanusi, Bachrawi. (2004). Tokoh Pemikir dalam Mąhab Ekonomi, Cet Pertama. Jakarta: Rineka Cipta.

Sejarah Krisis Ekonomi Dunia dikutip dari http://www.lintasberita.com/Sains/Sejarah Krisis Ekonomi Dunia, diakses pada 6 Juni 2009.

Susilo, Taufik Adi. (2009), Mengenal Amerika Serikat, cet 1. Yogyakarta: Ar-Ruzz Media.

Tim Redaksi (2005). Kamus Besar Bahasa Indonesia. edisi ketiga, Jakarta: Balai Pustaka. 